\title{
Ulnar-Sided Traumatic Wrist Pain. High Resolution Ultrasound Effectiveness versus MRI Assessment and Accuracy
}

\author{
HEBA KAMAL, M.D. and NEVIEN EL-LEITHY, M.D. \\ The Department of Diagnostic and Interventional Radiology, Kasr Al-Aini, Faculty of Medicine, Egypt
}

\begin{abstract}
Background: This work was conducted to assess the effectiveness of high resolution Ultrasonography (USG) compared with Magnetic Resonance Imaging (MRI) in investigating causes of ulnar sided wrist pain in traumatic patients, as this entity represents a diagnostic dilemma, owing to the anatomical complexity and small sized structures, as well as diversity of causes. Imaging plays an important role in guiding the diagnosis and minimizing unwanted surgical interventions.
\end{abstract}

Aim of Study: To evaluate the diagnostic performance of both ultrasonography and MRI in ulnar sided wrist pain, highlightening both the strengths and weaknesses of these two imaging modalities.

Patients and Methods: This study included fifty patients presenting with ulnar sided wrist pain. MRI and Ultrasonography were done in all patients.

Results: Out of 50 patients, 30 males (60\%) and 20 females (40\%), age ranging 23-65 years, were included in this study. A comparative analysis was done using MRI versus USG findings. The sensitivity, specificity, and accuracy of USG for Scapho-lunate ligament injury were $45.5 \%, 100 \%, 88 \%$ respectively, as MRI was positive in 11 cases, while USG only diagnosed 5 cases. The sensitivity, specificity, and accuracy for Triangular Fibrocartilage (TFCC) tear, were $64.71 \%, 90.91 \%$ and $82 \%$ respectively, as MRI was positive in 17 cases, while USG diagnosed 14 cases. For Extensor Carpi Ulnaris (ECU) injury, were $100 \%, 89.1 \%$ and $92 \%$ respectively, as MRI was positive in 13 cases, while USG diagnosed 17 cases. For extensor carpi ulnaris tendon subluxation, were $100 \%, 100 \%$ and $100 \%$ respectively, as both modalities were successful in diagnosing the same three cases, for ganglion cysts, were $100 \%, 100 \%$ and $100 \%$ respectively. For trabecular bone edema, MRI was positive in 24 cases, and for distal radioulnar joint instability MRI was positive in 9 cases, which were not diagnosed by USG, with lack of agreement between both modalities

Conclusion: Both magnetic resonance imaging and musculoskeletal ultrasound are essential and complement each other in the evaluation of causes of ulnar sided wrist pain in trauma patients. Musculoskeletal ultrasound is highly recommended for the examination of tendon injuries, while MRI is

Correspondence to: Dr. Heba Ahmed Kamal, E-Mail: hebakamala@gmail.com more efficient and suitable for assessing deeper structures, such as bone or ligaments.

Key Words: Ultrasonography (USG) - Magnetic resonance imaging (MRI) - Ulnar sided wrist pain.

\section{Introduction}

ULNAR sided wrist pain is a diagnostic challenge. This is due to the diversity and anatomical complexity in this region. Causes of ulnar-sided wrist pain can be categorized based upon its structural anatomy, including soft tissue and osseous causes [1].

The ulnar side of the wrist is known to be the "black box" of the wrist. This is due to the different structures that can be possibly injured, as well as, due to the particular biomechanical properties of the ulnar side of the wrist. Injury in this region can be disabling because of limitation of pronationsupination during different sports activities, such as tennis and golf [2].

Ultrasound (US) examination is widely popular and preferred, due to its portability, low cost and absence of ionizing radiation. It is mainly used for evaluating the soft tissues of the wrist, although it can provide some osseous details [3].

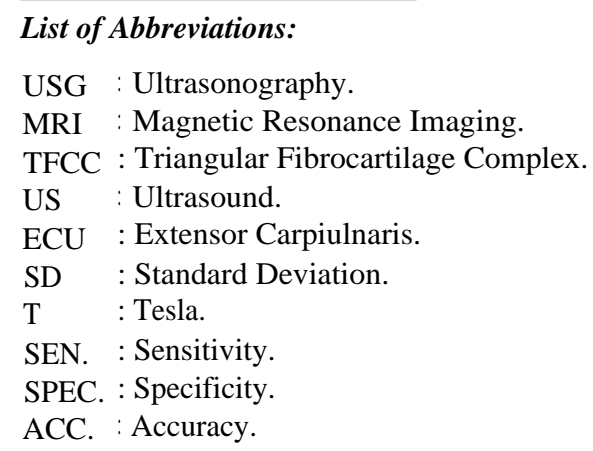


The imaging capability of US, its practicality, and dynamic component have led to the increased use of US as a preferable imaging modality in screening trauma patients presenting with pain at the ulnar side of the wrist [3]

Recent advances in MRI including high resolution techniques and highly specialized wrist coils, with more bone and soft tissue details, have increased the diagnostic performance of wrist MR imaging. MRI limitations include being expensive, time consuming, susceptible for motion artifacts and lack of dynamic capabilities compared with ultrasound. Patients may be claustrophobic or MRI may be contraindicated due to a pacemaker or incompatible vascular implants [3]

The purpose of this study was to evaluate the effectiveness of high resolution Ultrasonography (USG) compared with Magnetic Resonance Imaging (MRI) in investigating causes of ulnar sided wrist pain in traumatic patients.

\section{Methods}

\section{1- Patients:}

We performed a non-randomized control study for post traumatic patients complaining from ulnar sided wrist pain, who were diagnosed and sent from the orthopedic outpatient clinic to the Radi- ology Department, during the time span from January 2020 to January 2021 . The study included fifty patients; 30 males, 20 females with age ranging from 23 to 65 years. Written informed consents were collected from all patients.

All patients had clinical history taking, examined thoroughly by an orthopedic specialist, who did the referral to our department. Preliminary Xray study for the patients in the standard planes were done, followed by ultrasound and MRI studies.

\section{2- MR protocol:}

MRI was performed using Philips scanners Achieva or Intera (1.5T) (Philips medical systems, Best, the Netherlands).

\section{Patient position:}

The patients had their MRI study while lying supine on the examination table, with the arm beside the body and the dorsum of the hand parallel to the coronal plane of the magnet.

A circular coil (C200) was fitted tightly and securely over the wrist joint, by using rubber bands.

The examination protocol included coronal, sagittal and axial planes in different sequences, as outlined in (Table 1).

Table (1): MRI protocol.

\begin{tabular}{lcccccc}
\hline Parameters & Axial T1 & Axial T2 & $\begin{array}{c}\text { Sagittal } \\
\text { PD SPAIR }\end{array}$ & $\begin{array}{c}\text { Coronal } \\
\text { T1 }\end{array}$ & $\begin{array}{c}\text { Coronal } \\
\text { PD SPAIR }\end{array}$ & $\begin{array}{c}\text { Coronal } \\
\text { 3D WATS }\end{array}$ \\
\hline TE & 22 & 100 & 30 & 22 & 30 & 8 \\
TR & 533 & 4600 & 6100 & 450 & 3900 & 20 \\
Slice thickness (mm) & 2.5 & 2.5 & 2.5 & 2.5 & 2.5 & 1.5 \\
Gap (mm) & 0.3 & 0.3 & 0.3 & 0.3 & 0.3 & 0.8 \\
Flip angle & 90 & 90 & 90 & 90 & 90 & 90 \\
FOV (mm) & $80-100$ & $800-100$ & $80-100$ & $80-100$ & $80-100$ & $80-100$ \\
Matrix & 516 X 256 & 516 X 256 & 516 X 256 & 516 X 256 & 516 X 256 & 516 X 256 \\
\hline
\end{tabular}

In post contrast studies additional sequences were added, including T1 SPAIR in the three orthogonal planes. Gadopentetate dimeglumine (magnevist) was introduced through a cannula inserted in the contralateral arm at a dose of $0.2 \mathrm{ml} / \mathrm{kg}$ body weight.

The estimated examination time was from 25 minutes up to 40 minutes in case of contrast injection.
3- Ultrasonographic examination (Beggs et al., [4]): The study was conducted utilizing excess gel instead of the gel pad, using GE Logic pro6 (7-11 MHz) USA.

The patient was examined in the upright sitting position, his hand and wrist resting on a cushion, first pronated, then supinated, screening the different extensor compartments and major internal structures of the wrist joint Figs. (1-6). 


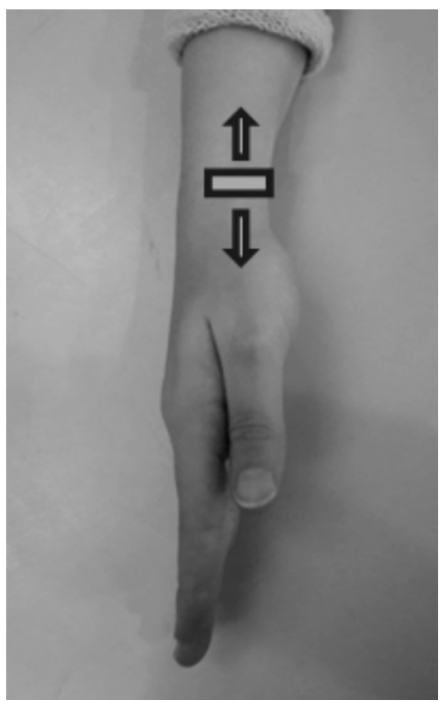

Fig. (1): Showing examination of the 1 st extensor compartment [5].

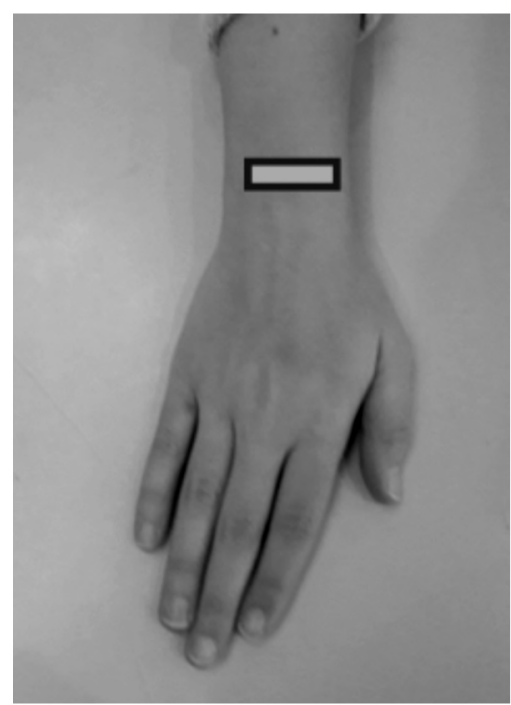

Fig. (3): Showing examination of the 3 rd extensor compartment [5].

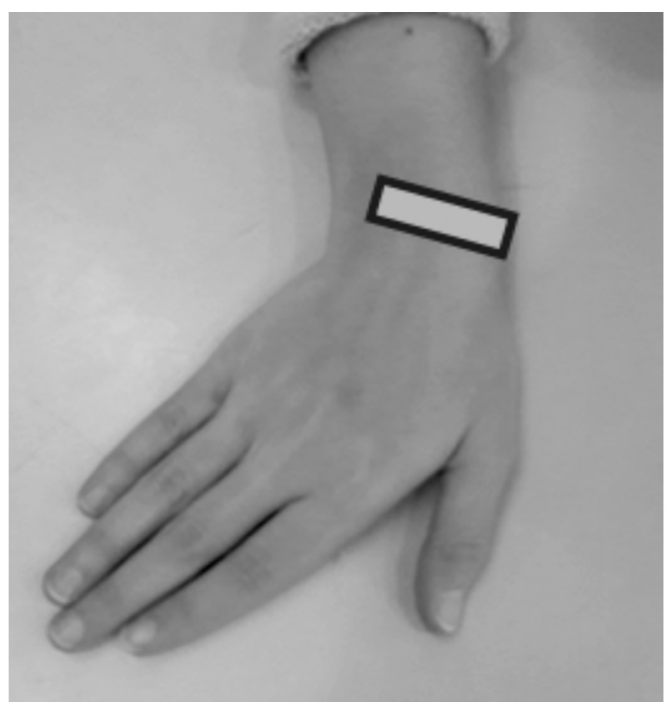

Fig. (5): Showing examination of the SL ligament [5].

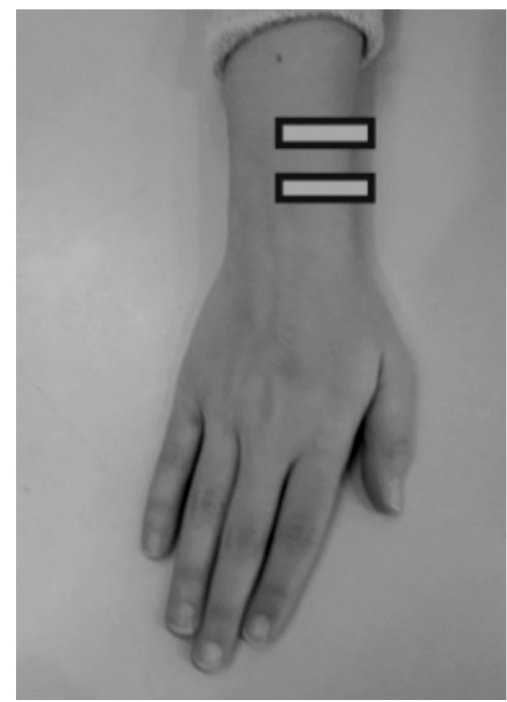

Fig. (2): Showing examination of the 2 nd extensor compartment [5]

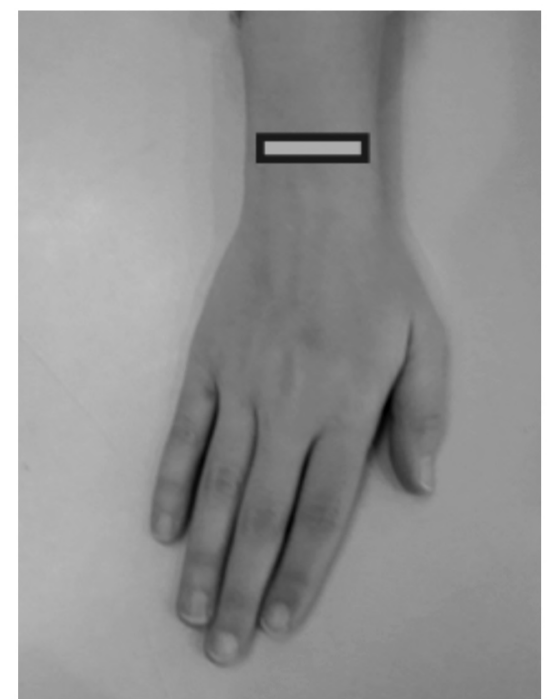

Fig. (4): Showing examination of the 4 th $\& 5$ th extensor compartments [5].

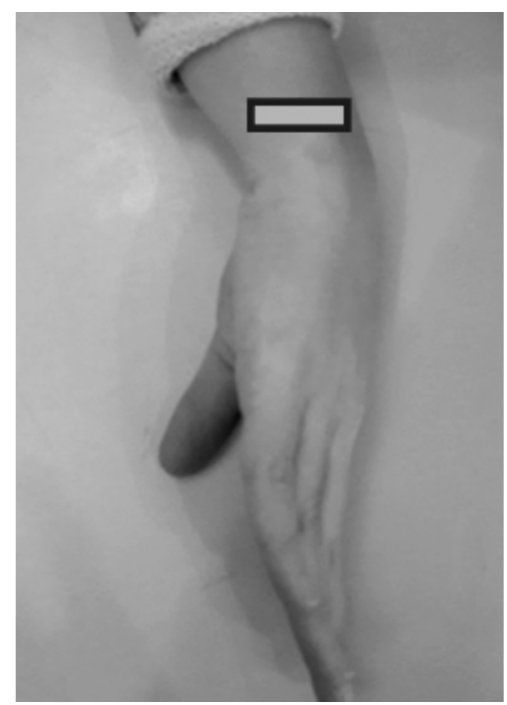

Fig. (6): Showing examination of the 6 th compartment [5]. 
Two different radiologists performed the ultrasound and MRI studies, each with an experience in musculoskeletal imaging more than 10 years, and both were blinded to the results of each modality to reduce bias. Statistical analysis and correlation was conducted between the results of USG versus MRI.

\section{4- The statistical methods in establishing the re- sults:}

Obtained data were statistically analyzed in the form of range, mean, Standard Deviation $( \pm S D)$, frequencies (number of cases) and percentages.

Categorical data comparison was done by using chi-square test. Exact test was used instead when the expected frequency is less than 5. Agreement between USG and MRI findings was obtained using kappa statistic.

Accuracy was represented by the terms of sensitivity, specificity, positive (+ve) predictive value, negative (-ve) predictive value, and overall accuracy. All calculations were performed by computer programs Microsoft Excel 2003 (Microsoft Corpo-

Table (2): Comparison between MRI and ultrasound in the detection of scapho-lunate ligament injury. ration, USA) and SPSS (Statistical Package for the Social Science; SPSS Inc., Chicago, USA) version 15 for Microsoft Windows.

Screening test done using medcalc version 18.9. Fisher exact correction done for comparison of qualitative variables.

\section{Results}

Ultrasound findings were correlated with MRI in assessing the different causes of traumatic ulnar sided wrist pain.

Scapholunate ligament injury; Fig. (7A-C) \& (Table 2). MRI detected this ligament injury in 11 joints while ultrasound detected it in 5 joints, missing 6 cases, demonstrating sensitivity: $45.45 \%$, specificity: $100 \%$ and accuracy: $88 \%$.

Triangular fibrocartilage Tear; Fig. (8A, B) \& (Table 3). MRI detected TFCC injury in 17 joints while ultrasound detected TFCC injury in 14 joints, with a SEN., SPE., \& ACC. of 64\%, 90\% \& 82\% respectively.

\begin{tabular}{|c|c|c|c|c|c|c|c|c|c|}
\hline \multirow{2}{*}{\multicolumn{2}{|c|}{ US-SL lig. injury }} & \multicolumn{2}{|c|}{$\begin{array}{l}\text { MRI -SL } \\
\text { lig. injury }\end{array}$} & \multirow{2}{*}{ Total } & \multirow{2}{*}{\multicolumn{2}{|c|}{$\begin{array}{l}\text { US-TFCC tear * MRI-TFCC tear } \\
\text { Crosstab }\end{array}$}} & \multicolumn{2}{|c|}{ MRI-TFCC tear } & \multirow[t]{2}{*}{ Total } \\
\hline & & \multicolumn{2}{|c|}{ Negative Positive } & & & & \multicolumn{2}{|c|}{ Negative Positive } & \\
\hline \multicolumn{5}{|l|}{ Negative: } & \multicolumn{2}{|l|}{$\begin{array}{l}\text { US-TFCC tear: } \\
\text { Negative: }\end{array}$} & & & \\
\hline \multirow{3}{*}{\multicolumn{2}{|c|}{$\begin{array}{l}\% \text { within US-SL lig. injury } \\
\% \text { within MRI-SL lig. Injury }\end{array}$}} & 39 & 6 & 45 & & 30 & 6 & 36 \\
\hline & & $86.7 \%$ & $13.3 \%$ & $100.0 \%$ & \multicolumn{2}{|c|}{$\%$ within US-TFCC tear } & $83.3 \%$ & $16.7 \%$ & $100.0 \%$ \\
\hline & & $100.0 \%$ & $54.5 \%$ & $90.0 \%$ & \multicolumn{2}{|c|}{$\%$ within MRI-TFCC tear } & $90.9 \%$ & $35.3 \%$ & $72.0 \%$ \\
\hline \multicolumn{2}{|c|}{$\%$ of total } & $78.0 \%$ & $12.0 \%$ & $90.0 \%$ & \multicolumn{2}{|c|}{$\%$ of total } & $60.0 \%$ & $12.0 \%$ & $72.0 \%$ \\
\hline \multicolumn{5}{|c|}{ Positive: } & \multicolumn{5}{|l|}{ Positive: } \\
\hline \multirow{4}{*}{\multicolumn{2}{|c|}{$\begin{array}{l}\text { Count } \\
\% \text { within US-SL lig. injury } \\
\% \text { within MRI-SL lig. Injury } \\
\% \text { of total }\end{array}$}} & 0 & 5 & 5 & \multirow{4}{*}{\multicolumn{2}{|c|}{$\begin{array}{l}\text { Count } \\
\% \text { within US-TFCC tear } \\
\% \text { within MRI-TFCC tear } \\
\% \text { of total }\end{array}$}} & 3 & 11 & 14 \\
\hline & & $0.0 \%$ & $100.0 \%$ & $100.0 \%$ & & & $21.4 \%$ & $78.6 \%$ & $100.0 \%$ \\
\hline & & $0.0 \%$ & $45.5 \%$ & $10.0 \%$ & & & $9.1 \%$ & $64.7 \%$ & $28.0 \%$ \\
\hline & & $0.0 \%$ & $10.0 \%$ & $10.0 \%$ & & & $6.0 \%$ & $22.0 \%$ & $28.0 \%$ \\
\hline \multirow{7}{*}{$\begin{array}{l}\text { Total: } \\
\text { Count } \\
\% \text { within US-SL lig. in } \\
\% \text { within MRI-SL lig. } \\
\% \text { of Total }\end{array}$} & & & & & \multicolumn{5}{|l|}{ Total: } \\
\hline & & 39 & 11 & 50 & Count & & 33 & 17 & 50 \\
\hline & injury & $78.0 \%$ & $22.0 \%$ & $100.0 \%$ & $\%$ within US-TFCC te & & $66.0 \%$ & $34.0 \%$ & $100.0 \%$ \\
\hline & Injury & $100.0 \%$ & $100.0 \%$ & $100.0 \%$ & $\%$ within MRI-TFCC & tear & $100.0 \%$ & $100.0 \% 1$ & $100.0 \%$ \\
\hline & & $78.0 \%$ & $22.0 \%$ & $100.0 \%$ & $\%$ of Total & & $66.0 \%$ & $34.0 \% \quad 1$ & $100.0 \%$ \\
\hline & \multicolumn{4}{|c|}{ Symmetric measures } & & \multicolumn{4}{|c|}{ Symmetric measures } \\
\hline & Value & $\begin{array}{l}\text { Asymp. S } \\
\text { Error(a }\end{array}$ & $\begin{array}{l}\text { Approx } \\
\mathrm{T}(\mathrm{b})\end{array}$ & $\begin{array}{c}p- \\
\text { value }\end{array}$ & & Value ${ }^{A}$ & $\begin{array}{l}\text { Asymp. Std. } \\
\text { Error(a) }\end{array}$ & $\begin{array}{l}\text { Approx } \\
\text { T(b) }\end{array}$ & $\begin{array}{c}p- \\
\text { value }\end{array}$ \\
\hline $\begin{array}{l}\text { - Measure of agreement } \\
\text { Kappa }\end{array}$ & 0.565 & 0.150 & 4.438 & 0.000 & $\begin{array}{l}\text { - Measure of agreement } \\
\text { Kappa }\end{array}$ & 0.581 & 0.124 & 4.149 & 0.000 \\
\hline - $\mathrm{N}$ of valid cases & 50 & & & & $\cdot \mathrm{N}$ of valid cases & 50 & & & \\
\hline
\end{tabular}



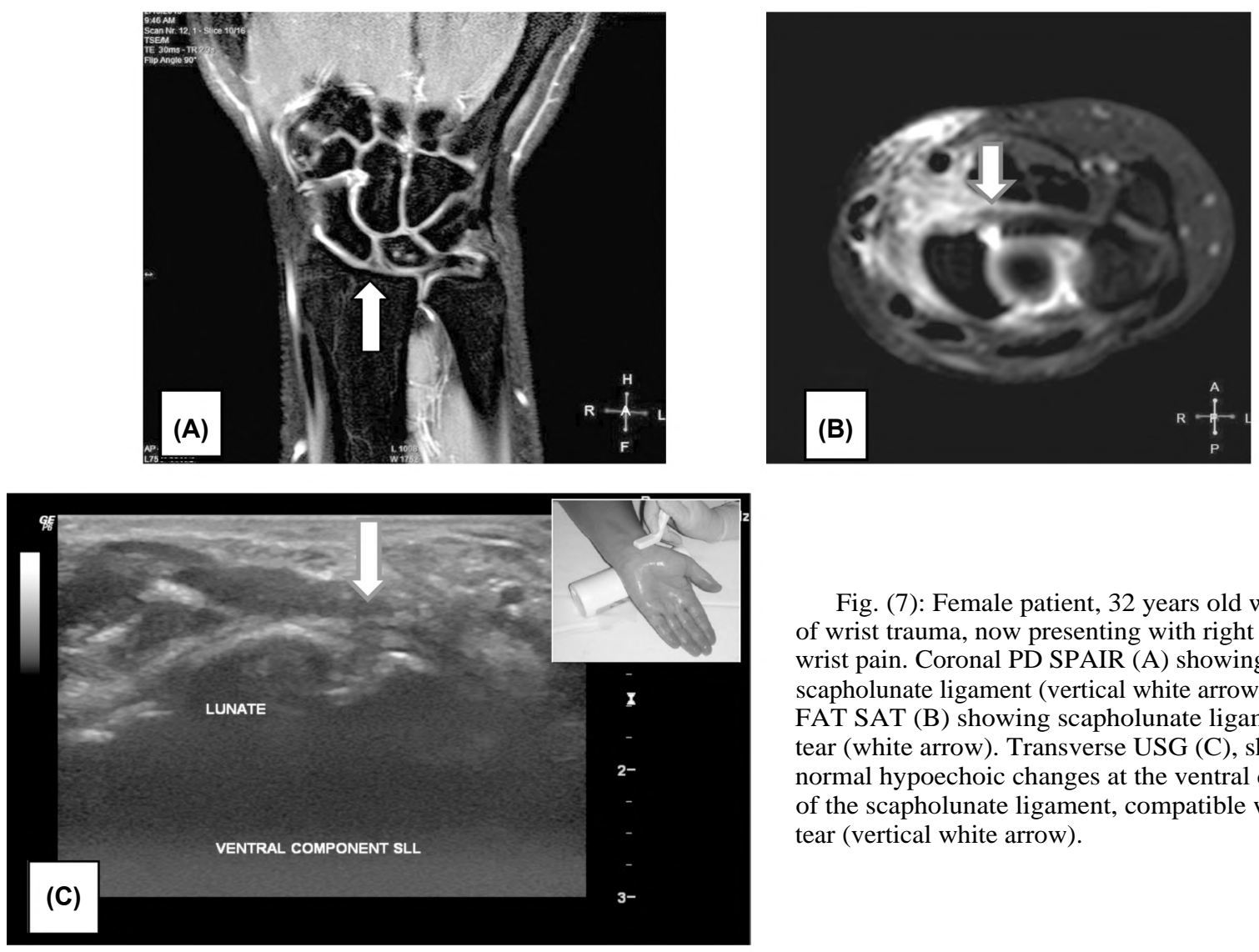

Fig. (7): Female patient, 32 years old with history of wrist trauma, now presenting with right ulnar sided wrist pain. Coronal PD SPAIR (A) showing tear of the scapholunate ligament (vertical white arrow). Axial T1 FAT SAT (B) showing scapholunate ligament partial tear (white arrow). Transverse USG (C), showing abnormal hypoechoic changes at the ventral component of the scapholunate ligament, compatible with partial tear (vertical white arrow).
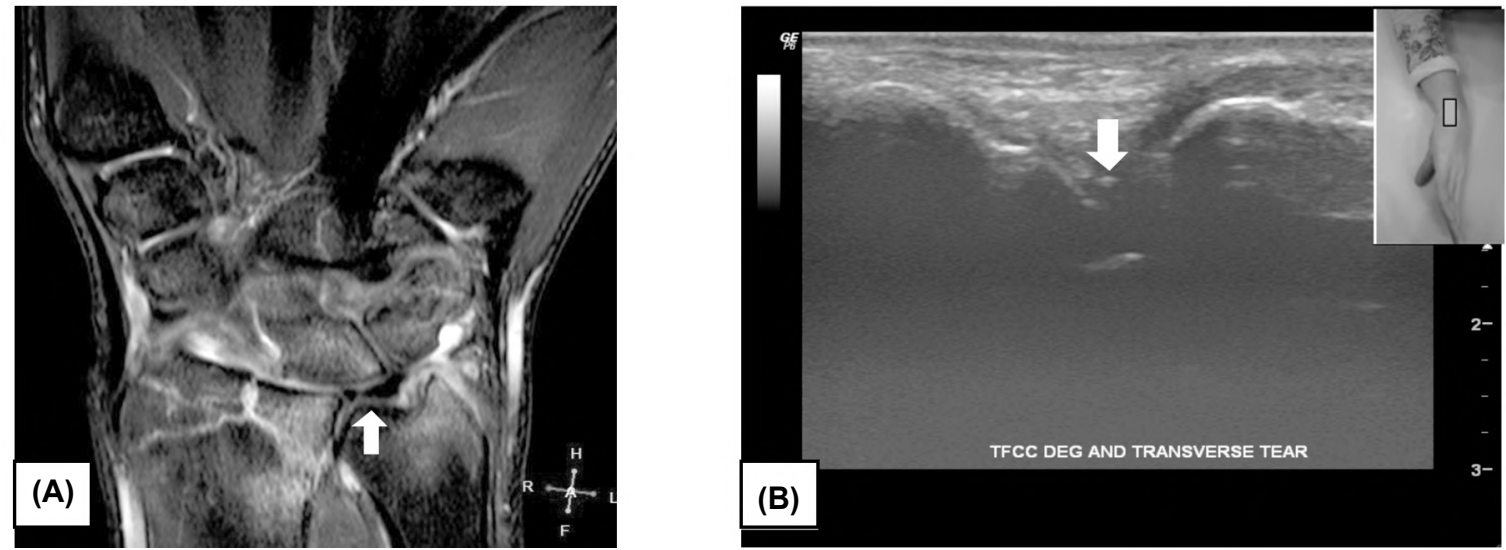

Fig. (8): Male patient, 27 years old with history of wrist trauma, now presenting with right ulnar sided wrist pain. Coronal T2 SPAIR (A) showing comminuted fracture of the distal radius and vertical tear of the radial attachment of TFC (white arrow). Longitudinal USG (B) showing triangular fibrocartilage hypoechoic full thickness tear (white arrow).

Extensor Carpi Ulnaris (ECU) injury Fig. (9A, B) \& (Table 4). MRI detected ECU injury in 13 joints while ultrasound detected it in 17 joints, with a SEN, SPE \& ACC of $100 \%, 89.1 \%, \& 92 \%$ respectively.

Extensor Carpi Ulnaris (ECU) subluxation Fig. $(10 \mathrm{~A}-\mathrm{C})$ \& (Table 5). Both USG \& MRI diagnosed the same 3 cases with ECU subluxation, with SEN, SPE \& ACC of $100 \%, 100 \%$ \& $100 \%$ respectively.
Ganglion cysts; Fig. (1 1A-D) \& (Table 6). Both USG \& MRI diagnosed 9 cases with ganglion cysts, with a SEN, SPE \& ACC of 100\%, 100\%, \& $100 \%$.

Trabecular bone edema; (Table 7). MRI detected trabecular bone edema in 24 joints that were not detected by ultrasound. They both showed no agreement in the detection of trabecular bone edema. 
Table (4): Comparison between MRI and ultrasound in the detection of extensor carpi ulnaris (ECU) injury.

\begin{tabular}{llll}
\hline \multirow{2}{*}{ Crosstab } & \multicolumn{2}{c}{ Ecu tear-MRI } & \multirow{2}{*}{ Total } \\
\cline { 2 - 3 } & \multicolumn{1}{c}{$\mathrm{N}$} & $\mathrm{P}$ & \\
\hline Ecu tear-US: & & & \\
$N$ : & & & \\
Count & 33 & 0 & 33 \\
$\%$ within Ecu tear-US & $100.0 \%$ & $0.0 \%$ & $100.0 \%$ \\
$\%$ within Ecu tear-MRI & $89.2 \%$ & $0.0 \%$ & $66.0 \%$ \\
$\%$ of total & $60.0 \%$ & $0.0 \%$ & $66.0 \%$ \\
$P:$ & & & \\
Count & 4 & 13 & 17 \\
$\%$ within Ecu tear-US & $23.5 \%$ & $76.5 \%$ & $100.0 \%$ \\
$\%$ within Ecu tear-MRI & $10.8 \%$ & $100.0 \%$ & $34.0 \%$ \\
$\%$ of total & $8.0 \%$ & $26.0 \%$ & $34.0 \%$ \\
\hline Total: & & & \\
Count & & 13 & 50 \\
$\%$ within Ecu tear-US & $74.0 \%$ & $26.0 \%$ & $100.0 \%$ \\
$\%$ within Ecu tear-MRI & $100.0 \%$ & $100.0 \%$ & $100.0 \%$ \\
$\%$ of Total & $74.0 \%$ & $26.0 \%$ & $100.0 \%$ \\
\hline
\end{tabular}

\begin{tabular}{llccc}
\hline & \multicolumn{4}{c}{ Symmetric measures } \\
\cline { 2 - 5 } & Value & $\begin{array}{c}\text { Asymp. Std. } \\
\text { Error(a) }\end{array}$ & $\begin{array}{c}\text { Approx } \\
\text { T(b) }\end{array}$ & $\begin{array}{c}p \text { - } \\
\text { value }\end{array}$ \\
\hline - Measure of agreement & 0.811 & 0.089 & 5.840 & 0.000 \\
$\begin{array}{l}\text { Kappa } \\
\text { - N of valid cases }\end{array}$ & 50 & & & \\
\hline
\end{tabular}

a: Not assuming the null hypothesis.

b: Using the asymptotic standard error assuming the null hypothesis.
Table (5): Comparison between MRI and ultrasound in the detection of extensor carpi ulnaris (ECU) sublaxation.

\begin{tabular}{cc}
\multirow{2}{*}{ Crosstab } & \multicolumn{2}{c}{$\begin{array}{c}\text { Ecu sublaxation } \\
\text { - MRI }\end{array}$} \\
\cline { 2 - 3 } & $\mathrm{N} \quad \mathrm{P}$ \\
\hline
\end{tabular}

\section{Ecu sublaxation-US:}

$N$ :

$\begin{array}{llll}\text { Count } & 47 & 0 & 47 \\ \% \text { within Ecu sublaxation-US } & 100.0 \% & 0.0 \% & 100.0 \% \\ \% \text { within Ecu sublaxation-MRI } & 100.0 \% & 0.0 \% & 94.0 \% \\ \% \text { of total } & 94.0 \% & 0.0 \% & 94.0 \%\end{array}$

$P$ :

Count $\quad \begin{array}{llll}0 & 3 & 3\end{array}$

$\%$ within Ecu sublaxation-US $\quad 0.0 \% \quad 100.0 \% \quad 100.0 \%$

$\%$ within Ecu sublaxation-MRI $0.0 \% \quad 100.0 \% \quad 6.0 \%$

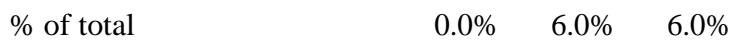

$\begin{array}{llll}\text { Total: } & & & \\ \text { Count } & 47 & 3 & 50 \\ \% \text { within Ecu sublaxation-US } & 94.0 \% & 6.0 \% & 100.0 \% \\ \% \text { within Ecu sublaxation-MRI } & 100.0 \% & 100.0 \% & 100.0 \% \\ \text { \% of Total } & 94.0 \% & 6.0 \% & 100.0 \%\end{array}$

\begin{tabular}{lllll}
\hline & \multicolumn{3}{c}{ Symmetric measures } \\
\cline { 2 - 5 } & Value & $\begin{array}{c}\text { Asymp. Std. } \\
\text { Error(a) }\end{array}$ & $\begin{array}{c}\text { Approx } \\
\mathrm{T}(\mathrm{b})\end{array}$ & $\begin{array}{c}p \text { - } \\
\text { value }\end{array}$ \\
\hline $\begin{array}{l}\text { - Measure of agreement } \\
\text { Kappa }\end{array}$ & 1.000 & 0.000 & 7.071 & 0.000 \\
- N of valid cases & 50 & & & \\
\hline a: Not assuming the null hypothesis. \\
b: Using the asymptotic standard error assuming the null hypothesis.
\end{tabular}
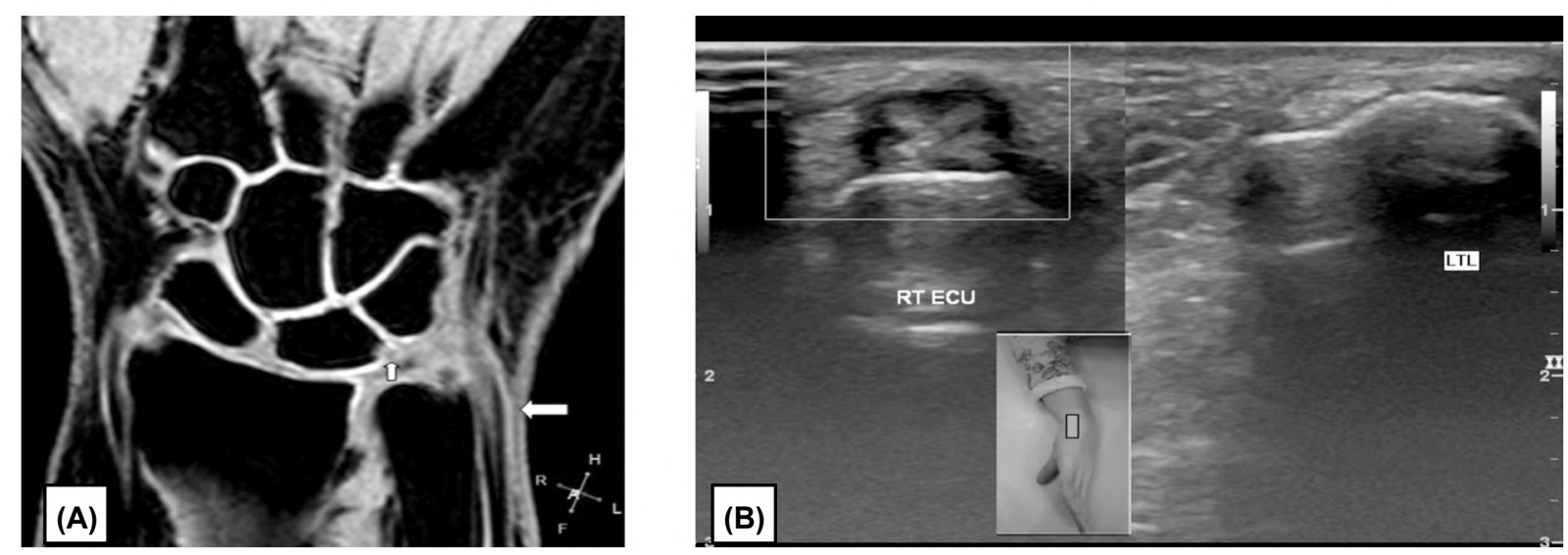

Fig. (9): Female patient, 38 years old with history of wrist trauma, now presenting with right ulnar sided wrist pain. Coronal 3D WATS (A) showing thickening and interstitial bright signal of the ECU tendon (white horizontal arrow) and chondromalacia of the proximal pole of lunate bone (small white arrow). Transverse USG (B) comparing the abnormal appearance of the affected ECU tendon (right side image), which is seen thickened, with distortion of its fibrillary pattern, with surrounding hypoechoic rim of tenosynovitis, compared to the contralateral normal side. 

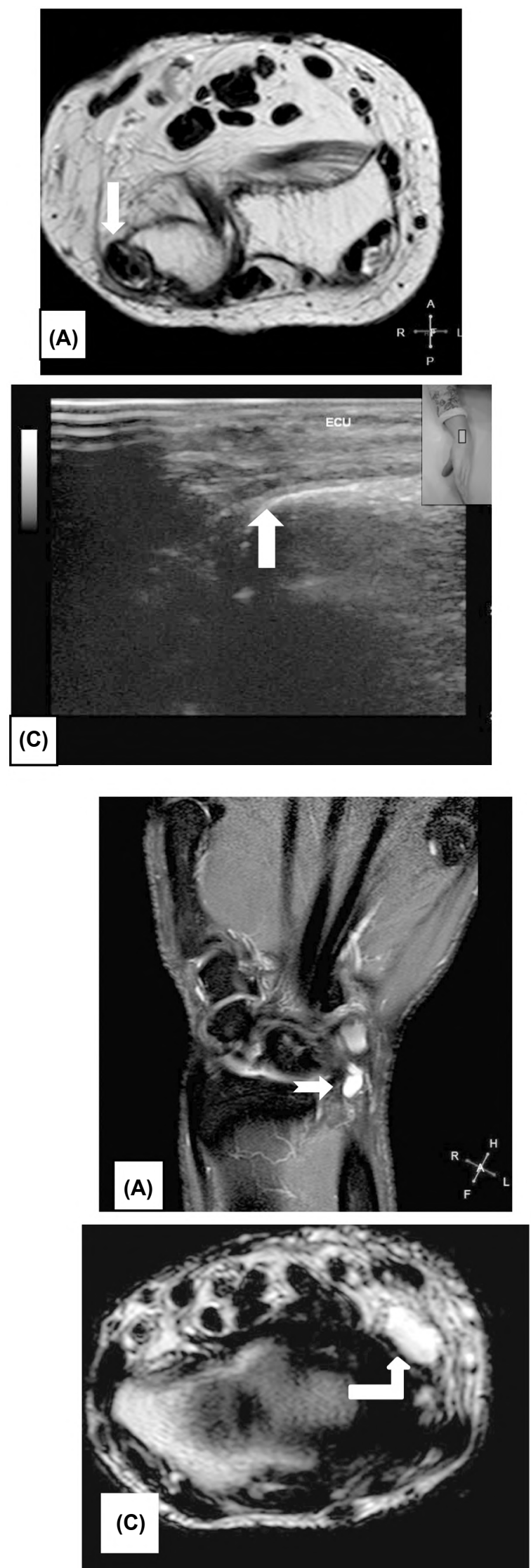

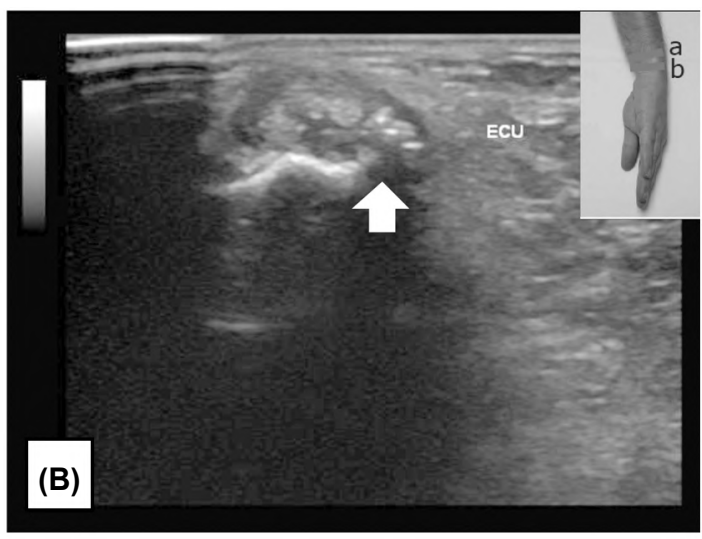

Fig. (10): Female patient, 54 years old with history of wrist trauma, now presenting with right ulnar sided wrist pain. Axial T2 (A) showing thickened ECU, with minimal tenosynovitis and partially subluxated outside its bony groove. Transverse USG (B) \& longitudinal USG (C) showing partial tear of the ECU tendon with partial subluxation evident at (B) (white arrow).
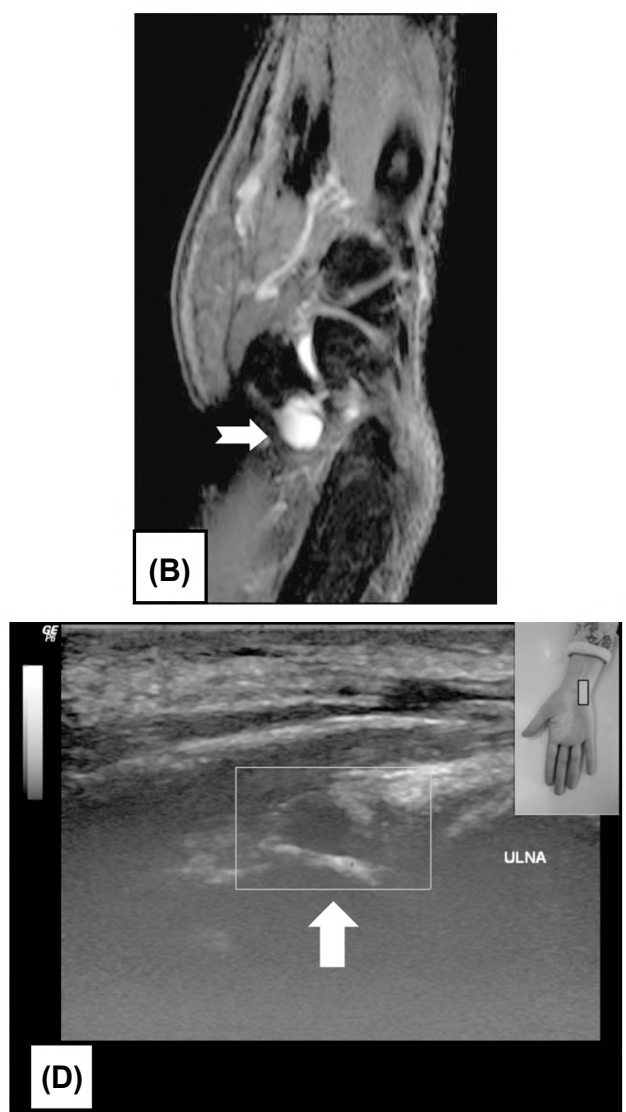

Fig. (11): Male patient, 31 years old with history of repeated trauma as the patient works as a carpenter, now presenting with left ulnar sided wrist pain. Coronal PD SPAIR (A), Sagittal PD SPAIR (B), and axial T2 (C) showing ganglion cyst related to the ventral aspect of the triangular fibrocartilage (white arrows). Longitudinal USG (D) confirming the presence of loculated fluid collection along the ventral aspect of TFC (white arrow). 
Table (6): Comparison between MRI and ultrasound in the detection of ganglion cysts.

\begin{tabular}{|c|c|c|c|c|}
\hline \multirow{2}{*}{\multicolumn{2}{|c|}{ Crosstab }} & \multicolumn{2}{|c|}{$\begin{array}{l}\text { Ganglion cysts } \\
\text { - MRI }\end{array}$} & \multirow[t]{2}{*}{ Total } \\
\hline & & \multirow[t]{2}{*}{$\mathrm{N}$} & $\mathrm{P}$ & \\
\hline \multicolumn{4}{|l|}{ Ganglion cysts-US: } & \\
\hline \multicolumn{5}{|l|}{$N:$} \\
\hline \multicolumn{2}{|l|}{ Count } & 41 & 0 & 43 \\
\hline \multicolumn{2}{|c|}{$\%$ within Ganglion cysts-US } & $100.0 \%$ & $0.0 \%$ & $100.0 \%$ \\
\hline \multicolumn{2}{|c|}{$\%$ within Ganglion cysts-MRI } & I $\quad 100.0 \%$ & $0.0 \%$ & $86.0 \%$ \\
\hline \multicolumn{2}{|c|}{$\%$ of total } & $82.0 \%$ & $0.0 \%$ & $86.0 \%$ \\
\hline \multicolumn{5}{|l|}{$P:$} \\
\hline \multicolumn{2}{|l|}{ Count } & 0 & 9 & 9 \\
\hline \multicolumn{2}{|c|}{$\%$ within Ganglion cysts-US } & $0.0 \%$ & $100.0 \% \quad 1$ & $100.0 \%$ \\
\hline \multicolumn{2}{|c|}{$\%$ within Ganglion cysts-MRI } & $0.0 \%$ & $100.0 \% \quad 1$ & $14.0 \%$ \\
\hline \multicolumn{2}{|c|}{$\%$ of total } & $0.0 \%$ & $14.0 \% \quad 1$ & $14.0 \%$ \\
\hline \multicolumn{5}{|l|}{ Total: } \\
\hline \multicolumn{2}{|l|}{ Count } & 41 & 9 & 50 \\
\hline \multirow{3}{*}{\multicolumn{2}{|c|}{$\begin{array}{l}\% \text { within Ganglion cysts-US } \\
\% \text { within Ganglion cysts-MRI } \\
\% \text { of Total }\end{array}$}} & $82.0 \%$ & $18.0 \%$ & $100.0 \%$ \\
\hline & & $100.0 \%$ & $100.0 \% \quad 1$ & $100.0 \%$ \\
\hline & & $82.0 \%$ & $18.0 \%$ & $100.0 \%$ \\
\hline & \multicolumn{4}{|c|}{ Symmetric measures } \\
\hline & Value & $\begin{array}{l}\text { Asymp. St } \\
\text { Error(a) }\end{array}$ & $\begin{array}{c}\text { d. Approx } \\
\text { T(b) }\end{array}$ & $\begin{array}{c}p- \\
\text { value }\end{array}$ \\
\hline $\begin{array}{l}\text { - Measure of agreement } \\
\text { Kappa }\end{array}$ & 0.852 & 0.102 & 6.089 & 0.000 \\
\hline$\cdot \mathrm{N}$ of valid cases & 50 & & & \\
\hline
\end{tabular}

Table (7): Comparison between MRI and ultrasound for the detection of trabecular bone edema.

\begin{tabular}{|c|c|c|c|}
\hline \multirow[t]{2}{*}{ Crosstabulation } & \multicolumn{2}{|c|}{$\begin{array}{c}\text { Trab. bone } \\
\text { edema (MRI) }\end{array}$} & \multirow[t]{2}{*}{ Total } \\
\hline & $\mathrm{N}$ & $P$ & \\
\hline \multicolumn{4}{|l|}{ Trab. bone edema-US: } \\
\hline \multicolumn{4}{|l|}{$N:$} \\
\hline Count & 26 & 24 & 50 \\
\hline$\%$ within Trab. bone edema-US & $52.0 \%$ & $48.0 \%$ & $100.0 \%$ \\
\hline$\%$ within Trab. bone edema-MRI & $100.0 \%$ & $100.0 \%$ & $100.0 \%$ \\
\hline$\%$ of total & $52.0 \%$ & $48.0 \%$ & $100.0 \%$ \\
\hline \multicolumn{4}{|l|}{ Total: } \\
\hline Count & 26 & 24 & 50 \\
\hline$\%$ within Trab. bone edema-US & $52.0 \%$ & $48.0 \%$ & $100.0 \%$ \\
\hline$\%$ within Trab. bone edema-MRI & $100.0 \%$ & $100.0 \%$ & $100.0 \%$ \\
\hline \multirow[t]{2}{*}{$\%$ of Total } & $52.0 \%$ & $48.0 \%$ & $100.0 \%$ \\
\hline & \multicolumn{3}{|c|}{$\begin{array}{c}\text { Symmetric measures } \\
p \text {-value }\end{array}$} \\
\hline $\begin{array}{l}\text { Measure of agreement Kappa } \\
\mathrm{N} \text { of valid cases }\end{array}$ & & $\begin{array}{l}1.000 \\
50\end{array}$ & \\
\hline
\end{tabular}

\section{Discussion}

Ulnar sided wrist pain in post trauma patients is a compound diagnostic dilemma, because of the small and diverse anatomical structures in a very narrow zone, as well as vague clinical symptoms, which are not specific to a particular pathology [1].

Several structures at the ulnar side of the wrist can be injured in the post traumatic patients and manifest by pain, examples include fractures, tendon ruptures and tendinopathies, ligaments tears, nerve injuries, carpal instability and ganglion cysts [1].

USG and MRI share a complementary role in imaging and diagnosing wrist pathologies. MRI can be accurate and sensitive in studying both soft tissue and osseous causes of wrist pain [5], while USG is more accurate in differentiating cystic from solid natured lesions, as well as studying tendinous structures, owing to its dynamic capability [6]

Technical advances in ultrasound and higher frequency transducers have resulted in its frequent use in the evaluation of internal composition of tendons and ligaments with superior resolution than in the past, providing orthopedics with a detailed morphological information regarding the integrity of these supporting structures [7]

Ultrasound is a valuable imaging modality in examining trauma patients presenting with ulnar sided wrist pain, owing to its ability to correlate the site of complain with the underlying sonographic appearance. The ability to dynamically assess the wrist and correlate with the contralateral asymptomatic wrist for comparison purposes are the main advantages of ultrasound as a diagnostic tool [8]

Regarding the detection of scapholunate ligament injury by ultrasound, Taljanovic et al., [9] detected a sensitivity of $50 \%$ and a specificity of $90 \%$. Our results concerning the detection of scapholunate ligament injury using ultrasound compared to MRI showed rather similar results as we detected a sensitivity of $45.45 \%$ and a specificity of $100 \%$.

Finlay et al., [10] study suggests that ultrasound is currently not a good screening modality for detection of scapholunate ligament tears, with a sensitivity of only $25 \%$ which did not agree with our results, this difference could be attributed to the recent advances of ultrasound techniques which allowed a better visualization of internal structures of the wrist joint. 
Regarding the evaluation of the triangular fibrocartilage by ultrasound compared to MRI, our study showed a sensitivity of $64.71 \%$, a specificity of $90.91 \%$ and an accuracy of $82 \%$ in case of TFCC. Our results matches results stated by Finlay et al., [10] who used conventional arthrography as a gold standard, which showed a sensitivity approaching $64 \%$ and a diagnostic accuracy of $85 \%$ in the detection of TFCC tear. These results suggest that with training, experience and reliable technique, ultrasound may prove a reasonable screening modality for detection of triangular fibrocartilage injury.

A study was conducted by Chiou et al., [11], who performed high resolution ultrasound for evaluation of triangular fibrocartilage and compared his results to conventional arthrography. This study showed High Resolution Ultrasound (HRUS) of the triangular fibrocartilage to have a high specificity, PPV, NPV and accuracy and that this method can be used as an initial imaging modality to obviate arthrography in some cases. However this study stated that HRUS has a relatively low sensitivity of $68.4 \%$ and further extensive study should be done to assess its value in screening for triangular fibrocartilage tears, which also matched our results.

Keogh et al., [12] who studied ultrasound examination of triangular fibrocartilage and compared his results to the MRI and arthroscopy showed a sensitivity and specificity of $87.5 \%$ and $100 \%$ which did not match our results. May be because this study had several limitations one of them that the study group was selected and did not include asymptomatic patients with normal triangular fibrocartilage.

Regarding the ultrasound detection of Extensor Carpi Ulnaris (ECU) injury either tenosynovitis or tear compared to MRI, our study showed a sensitivity of $100 \%$, specificity of $89.19 \%$ and an accuracy of $92 \%$.

Ultrasound performs better than magnetic resonance imaging in the detection of partial tendon tears as revealed by Swen et al., [13] which matched our results.

Mihaela et al., [14] revealed that US evaluation of the tendons can be a reliable method in detection of inflammatory and structural tendon changes. However they also stated that in general, US evaluation of the tendons is difficult and may expose a not very experienced operator to erroneous interpretations of anisotropy artifact or normal anatomic structures (e.g. retinacula) in complex areas such as the wrist and ankle. This may explain the high sensitivity $(100 \%)$ and lower specificity $(89.19 \%)$ in our results concerning the detection of ECU tendon injury by ultrasound compared to MRI.

However, we found studies supporting the idea that both ultrasound and MRI have complementary roles in imaging tendon injury as Porteous et al., [1] who clarified that tenosynovitis is readily diagnosed on either ultrasound or MRI as thickening and fluid distension of the synovial sheath with or without intra-substance degeneration or tear of the tendon.

As regard the detection of ganglion cysts by ultrasound compared to MRI, our study revealed a sensitivity of $100 \%$, specificity of $100 \%$ and an accuracy of $100 \%$.

Harish et al., [8] stated that on ultrasound, ganglion cysts appear as non-compressible anechoic well defined lesions with posterior acoustic enhancement.

In a study conducted by Sofka [7], ultrasound was easily used for percutaneous aspiration and drainage of ganglion cysts.

Teefey et al., [15] showed that ultrasound has an extremely useful role in localizing lesions and determining if the lesion is cystic or solid, but further tissue characterization is limited.

All of the above studies confirmed the important role of ultrasound in the evaluation of ganglion cysts.

\section{Conclusion:}

Musculoskeletal ultrasound, although operator dependent, and its accuracy is directly correlated with the operator experience, it offers several essential advantages, being available, fast, cheap, and without ionizing radiation, making it well accepted and practical in the examination of post traumatic patient. It should be the first choice of studying the majority of cystic, tendinous and vascular pathologies, however ultrasound images of the triangular fibrocartilage and interosseous ligaments do not provide satisfactory information, thus MRI is better for evaluation of internal wrist derangement.

\section{References}

1- PORTEOUS R., HARISH S. and PARASU N.: Imaging of Ulnar-Sided Wrist Pain, Canadian Association of Radiologists Journal, 63: 18-29, 2012.

2- CANETE A.N., De JONGE M.C., NUSMAN C.M., TERRA M.P. and MAAS M.: Wrist and hand in Sports Injuries 
in Children and Adolescents, Med. Radiol. Diagn. Imaging, Springer-Verlag Berlin Heidelberg, p. 129, 2011.

3- LEE J.C. and HEALY J.C.: Normal sonographic anatomy of the wrist and hand. Radiographics, Nov.-Dec., 25 (6): 1577-90. doi: 10.1148/rg.256055028. PMID: 16284136, 2005.

4- BEGGS I., BIANCHI S., BUENO A., et al.: Musculoskeletal Ultrasound Technical guidelines: III. wrist Vienna, Austria: European Society of MusculoSkeletal Radiology from musculoskeletal ultrasound book by Ian Beggs, Lippincott,Williams and Wilkins, p79. Available at http:/ /www.CMr. org/html/img/pool/wrist. Pdf, 2001.

5- EL-KHOLY M.R., MAALY M.A. and HAMEEDA Y.H.: Role of MRI in evaluation of painful wrist joint. Menoufia Medical Journal, 28: 503-7, 2015.

6- ORMAN G., YESILADAL1 G., OLCAY E. and DUYMUS M.: Comparison of Ultrasonography and Magnetic Resonance Imaging for Diagnosis of Soft Tissue Masses of the Hand and Wrist. Eur. J. Gen. Med., 12 (1): 38-43. https://doi.org/10.15197/sabad.1.12.07, 2015.

7- SOFKA C.M.: Ultrasound of the Hand and Wrist, (Ultrasound Quarterly, 30: 184-92, 2014.

8- HARISH S., O'NEILL J., FINLAY K., JURRIAANS E. and FRIEDMAN L.: Ultrasound of Wrist Pain, CurrProbIDiagn. Radiol., 38: 111-25, 2009.

9- TALJANOVIC M.S., SHEPPARD J.E., JONES M.D. SWITLICK D.N., HUNTER T.B. and ROGERS L.F.: Sonography and sonoarthrography of the scapholunate and lunotriquetral ligaments and TFC: Initial experience and correlation with arthrography and magnetic resonance arthrography. J. Ultrasound. Med., 27 (2): 179-91, 2008.

10- FINLAY K., LEE R. and FRIEDMAN L.: Ultrasound of intrinsic wrist ligament and triangular fibrocartilage injuries. Skeletal Radiol., 33: 85-90, 2004.

11-CHIOU H.J., CHANG C.Y., CHOU Y.H., et al.: Triangular fibrocartilage of wrist: Presentation on high-resolution ultrasonography. J. Ultrasound Med., 17: 41-8, 1998.

12- KEOGH C.F., WONG A.D., WELLS N.J., BARBARIE J.E. and COOPERBERG P.L.: High-resolution US of the triangular fibrocartilage: Initial experience and correlation with MR imaging and arthroscopic findings. AJR Am. J. Roentgenol., 182: 333-6, 2004.

13- SWEN W.A., JACOBS J.W., HUBACH P.C., et al.: Comparison of sonography and magnetic resonance imaging for the diagnosis of partial tears of finger extensor tendons in rheumatoid arthritis. Rheumatology (Oxford), 39: 55$62,2000$.

14- MICU M.C., SERRA S., FODOR D., CRESPO M. and NAREDO E.: Inter-observer reliability of ultrasound detection of tendon abnormalities at the wrist and ankle in patients with rheumatoid arthritis. Rheumatology (Oxford), Jun., 50 (6): 1120-4. doi: 10.1093/rheumatology/ keq441. Epub. 2011 Jan. 25. PMID: 21266445, 2011.

15- TEEFEY S.A., MIDDLETON W.D. and BOYER M.I.: Sonography of the hand and wrist.Semin Ultrasound CT MR, 21: 192-204, 2000. 


\section{آلامم الرسغ الرضحية من جانب الزند.

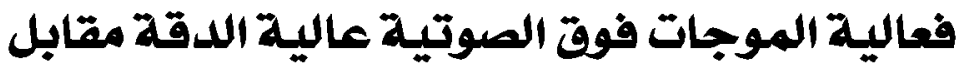

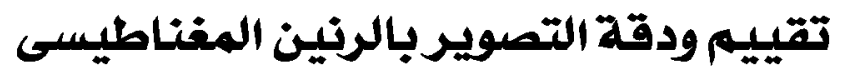

يعتبر آلم الجانب الداخلى للرسن معضلة تشخيصية وذلك نظراً لتعقيد تركيب هذه المنطقة، إن العرض الإكلينيكى لحالات آلم الجانب الداخلى الرسن يتنوع ما بين الإصابة الحادة والحالات المزمنة.

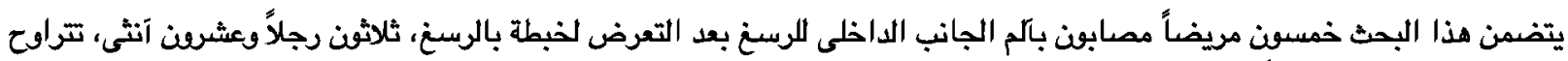

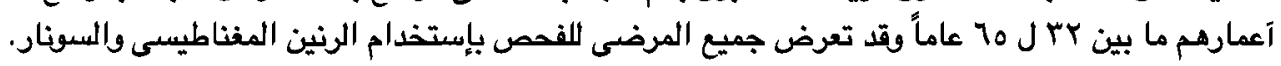

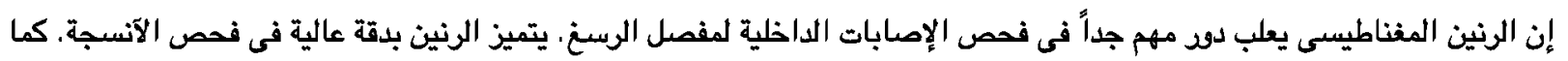

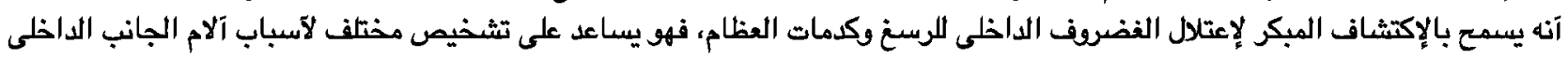

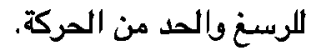

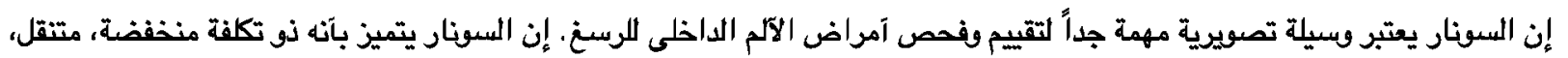

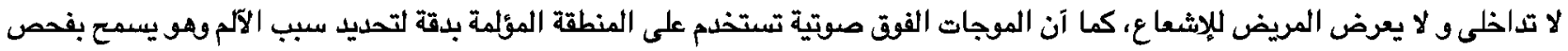
المفصل في مختلف الآوضاع.

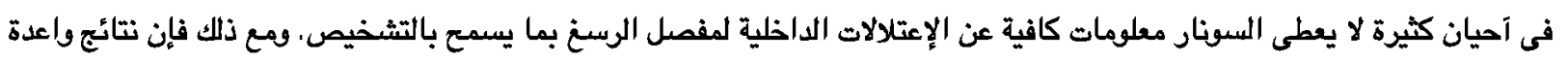

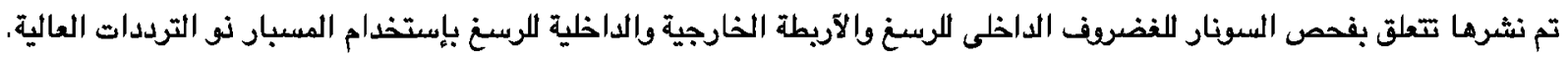
كما آن السونار يساعد في تثخيص الإرتشاح الداخلى المفصل وإصابات الآوتار والآربطة وإلتهابات الآوتار. وفى النهاية، يلعب كل من الرنين المفناطيسى والسونار آدواراً متكاملة فى تقييم الآسباب المختلفة لآلام الجانب الداخلى اللرسن، كما ينصح

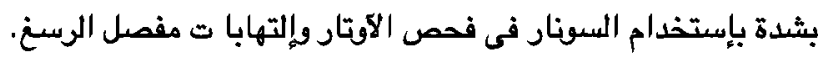
ومع ذلك، فإنه فى حالات الفضروف الداخلى والآريطة الداخلية الرسن، فإن السونار لا لإلعطى معلومات مرضية. لذا فإن الرنين المغناطيسى

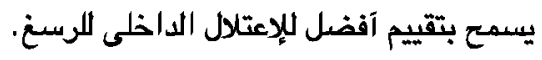
ومع ذللك، تم نشر دراسات واعدة تتعلق بفحص السونار للإعتلال الداخلى للرسن بإستخدام المسبار العالى التردد. 